\title{
Three interesting Cyprididae (Ostracoda) from Western Australia
}

\author{
Ivana Karanovic \\ Department of Terrestrial Zoology, Western Australian Museum, \\ Locked Bag 49, Welshpool DC, Western Australia 6986, Australia. \\ Present address: School of Zoology, University of Tasmania, \\ Private Bag 5, Hobart, Tasmania 7001, Australia.
}

\begin{abstract}
The paper contributes to the systematics of the family Cyprididae and to a description of the general ostracod biodiversity in Australia. Riocypris hinzeae sp. nov., is described from wells in the Murchison region (Western Australia). This is the second species described in the genus, previously known from South America. Another two species are transferred into this genus: Riocypris fitzroyi (McKenzie, 1966) comb. nov. and $R$. fontana (Graf, 1931) comb. nov. Cyprinotus cingalensis Brady, 1886, collected from wells in the Pilbara Region (Western Australia), is redescribed. Populations of some other described Cyprinotus species show extreme variability in morphology and length of the carapace and the following species are thus synonymized with $C$. cingalensis: $C$. dahli Sars, 1896; $C$. venoi Brehm, 1936; C. kimberleyensis McKenzie, 1966 and C. edwardi McKenzie, 1978. The morphological variability in carapace shape and uniformity of the internal morphology of the species Bennelongia australis s. 1. (Brady, 1886), here reported from the Murchison Region, confirms the need for a revision of the genus Bennelongia because correct identification of many representatives of this genus is almost impossible.
\end{abstract}

\section{INTRODUCTION}

In Australia, the family Cyprididae Baird, 1845, is represented by 11 subfamilies, 32 genera and 110 species. King (1855) first recorded this ostracod group in Australia but the most significant contributions to our recent knowledge of the living Cyprididae from this continent have been made by the late Dr Ken McKenzie and Professor Patrick De Deckker (McKenzie 1966a, 1966b, 1978; De Deckker 1974, 1976, 1979a, 1979b, 1981a, 1981b, 1981c, 1982a, $1982 b, 1982 c)$. Most recently Halse and McRae (2004), Martens et al. (2004) and Karanovic (2005a) described some new Cyprididae taxa, breaking an hiatus of more than 20 years since the last Cyprididae ostracod description from Australia.

The most diverse Cyprididae subfamily in Australia is Eucypridinae Bronstein, 1947 with eight genera and 26 species, followed by Herpetocypridinae Kaufmann, 1900 with five genera and 19 species. The rest of the nine Cyprididae subfamilies in Australia are represented as follows: Cyprettinae Hartmann, 1963 with two genera and eight species; Cypricercinae McKenzie, 1971 with two genera and five species; Cypridinae Baird, 1845 with two genera and 11 species; Cypridopsinae Kaufmann, 1900 with three genera and five species; Cyprinotinae Bronstein, 1947 with four genera and 14 species; Diacypridinae McKenzie, 1978 with two genera and 16 species; Ngarawinae De Deckker, 1979 with one genus and one species; and Scottiinae Bronstein, 1947 with two genera and four species. The subfamilies Diacypridinae and Ngarawinae are endemic to Australia.

According to Halse (2002) there are about 121 Cyprididae species recognized in Western Australia, of which only 55 have been described. In the present paper I report on three species collected from northwestern Western Australia during various investigations of the subterranean waters of the Murchison and Pilbara regions. They often occur in great numbers in wells although they are all surface water species. A new species of the genus Riocypris Klie, 1935 is described, a genus until now known only from the type species described from Uruguay (Klie 1935). Beside the new species, two other species already known from Australia, are transferred to the genus Riocypris. The second species dealing with in this paper is Cyprinotus cingalensis Brady, 1886, described from Southeast Asia (Brady 1886a), but latter found in Queensland (Sars 1889). After finding great variability in populations collected from the Pilbara region, the following species are synonymized with it: C. dahli Sars, 1897; C. kimberleyensis McKenzie, 1966 and C. uenoi Brehm, 1936. The last species presented in this paper is identified as Bennelongia australis s. 1. (Brady, 1986). While a detail revision of the genus Bennelongia De Deckker and McKenzie, 1981 is in progress (Martens and Halse, 
in preparation), the present record deals with the status of the genus in the subfamily Cypridinae. In general, this paper contributes to a better understanding of the entire family Cyprididae, both in Australia and globally. This family is in urgent need of revision. When Hartmann and Puri (1974) published their work on the classification of the Recent and Fossil ostracods, there were 21 subfamilies recognized in the family Cyprididae (the subfamily Cypridopsinae was given family status). This was, and still is by far the greatest number of subfamilies in any of the families of the superfamily Cypridoidea. According to Martens (1990) today about 30 subfamilies are recognized within the family Cyprididae, many of them hard to distinguish. Some of the subfamilies have been revised in the last 20 years (Martens 1986, 1989, $1990,1992)$ but there is still much work to be done to resolve the systematics of the family. This paper contributes to the systematics of the family with one new description and two redescriptions, a consideration of the taxonomy of the subfamily Eucipridinae, and by proposing some rearrangements of the genera within some other Cyprididae subfamilies.

\section{MATERIAL AND METHODS}

Samples were collected with haul-nets (mesh size 50,250 or 350 micrometers) from wells. Samples were sorted under a dissecting microscope, either while alive (sample prefix BES) or after fixation in $70 \%$ or $100 \%$ ethyl-alcohol (PSS).

Ostracods were dissected in a mixture of distilled water and glycerol $(1: 1)$ with fine entomological needles (size 000). Dissected appendages and valves of some specimens were mounted in Faure's medium. The appendages of some specimens were mounted on slides in glycerol, while their valves are kept on micropalaeontological slides or in glass test-tubes in $70 \%$ alcohol. All non-dissected material is preserved in $70 \%$ ethyl-alcohol in glass test-tubes. Drawings have been prepared using a drawing tube attachment on Leica-DMLS microscope, with C-PLAN achromatic objectives. All the material is deposited in the Western Australian Museum (WAM).

In the systematic part of this paper the length of all segments was measured in the middle of the segments, and length ratios are presented beginning with the proximal end. The terminology of the appendages follows Martens (1998), while chaetotaxy of all limbs follows the model proposed by Broodbakker \& Danielopol (1982), revised for the antenna by Martens (1987). Terminology of the second and third thoracopods follow Meisch (1996), while setae on the antennula are labeled according to Karanovic (2005b). No abbreviations are used in the text.

\section{SYSTEMATICS}

\section{Family Cyprididae Baird, 1845}

\section{Subfamily Eucypridinae Bronstein, 1947}

Genus Riocypris Klie, 1935

Riocypris Klie 1935: 289.

\section{Type species}

Riocypris uruguayensis Klie, 1935, by original designation.

\section{Other species}

Riocypris fitzroyi (McKenzie, 1966) comb. nov.; Riocypris hinzeae sp. nov.; and Riocypris fontana (Graf, 1931) comb. nov.

\section{Amended diagnosis}

Right valve with inwardly displaced selvage at least anteriorly. Selvage on left valve, if present, usually peripheral. Inner list prominent, especially on left valve. Maxillular palp cylindrical. First endopodal segment on antennula elongated. Prehensile palps asymmetrical, seta " $\mathrm{c}$ " absent on protopod of first thoracopod. Proximal basal seta on walking leg considerably longer than distal one (usually three times), penultimate segment on the same leg clearly divided. Penultimate segment on cleaning leg with only one seta. Caudal ramus thin and elongated, both claws and setae present, posterior seta not transformed into claw. Attachment simple.

\section{Remarks}

The genus Riocypris Klie, 1935, was described from Uruguay (Klie 1935), and was previously known from only the type species, $R$. uruguayensis Klie, 1935. The new species differs from the type species by the shape of the carapace which is highly arched in the type species, giving a triangular appearance to the carapace. The dorsal margin in the new species is slightly rounded, almost flat. In addition, the selvage is more inwardly placed in $R$. uruguayensis. In the diagnosis of the genus, Klie (1935) pointed out the internal morphology of the valves as one of the most important features, especially the asymmetry of the valves, where the right one has salvage inwardly placed. The internal morphology of the valves distinguishes the genus Riocypris from the closely related genus Eucypris Vávra, 1891, where selvage (if present) is always marginally situated (Martens 1989). The internal morphology of the genus Riocypris resembles that of the genera Prionocypris Brady and Norman, 1896, Tonnacypris Diebel and Pietrzeniuk, 1975, Trajancypris Martens, 1989 and Koencypris Meisch, 2000. All three genera are known only from the Palearctic, while the genus Eucypris has a 
Cosmopolitan distribution. From the genera Prionocypris, Tonnacypris and Trajancypris, the genus Riocypris differs by the cylindrical shape of the terminal segment of the maxillular palp. This segment is spatulate (distally enlarged) in the three genera. On the other hand, this segment is also cylindrical in the genus Koencypris, which is known only from the type species $K$. ornata (Müller, 1776), transferred from the genus Eucypris by Meisch (2000). The similarity between Koencypris and Riocypris is indeed large, but the caudal ramus in the former genus is much shorter than in the genus Riocypris. Unfortunately, Koencypris is known only from females. Beside the new species, I propose here to include the following two species in the genus Riocypris: Candonocypris fitzroyi McKenzie, 1966 and Eucypris fontana Graf, 1931. The first species was collected from the Fitzroy River in Western Australia (McKenzie, 1966b). The reason why McKenzie (1966b) included this species into the genus Candonocypris Sars, 1896, is not clear, as the main diagnostic character of the genus is the presence of two setae on the penultimate segment of the cleaning leg, but this was not described for $C$. fitzroyi. I believe that this species could not possibly belong to the genus Candonocypris because of the shape of the terminal segment of the maxillular palp, which is spatulate in all species, while in C. fitzroyi it is cylindrical. Also, species of the genus Candonocypris have more claw-like appearance of the posterior seta on the caudal ramus, while it is clearly seta like in $C$. fitzroyi. Riocypris fitzroyi (McKenzie, 1966) comb. nov. is in fact very similar to $R$. hinzeae sp. nov. having an almost identical valve shape and also the internal morphology of the valves. They differ in the length of the anterior seta on the caudal ramus, which is much longer in $R$. fitzrovi. Also, this species has a longer posterior claw, compared with the anterior one, than the new species. Riocypris fitzroyi is known only from females, and possible finding of males may eventually reveal even greater proximity of the two species. Eucypris fontana (Graf, 1931) was described from South Georgia, and later recorded from Signy Island, both in the subAntarctic (De Deckker 1981c). In this species, the selvage is clearly inwardly displaced anteriorly on the right valve, while it is peripheral on the left one. However, De Deckker (1981c) claimed that the position of selvage is typical for Eucypris species, which obviously is not correct. The presence of the knobs on the outside of the shell near the anterior margin (best observed in dorsal view) visible on the E. fontana, and common in the genus Eucypris led De Deckker (1981c) to the wrong conclusion. Riocypris fontana (Graf, 1931) comb. nov., also known only from females, differs from the other species of the genus by its ornamented shell.

Eucypris oblonga (Sars, 1896) should tentatively be included in the genus Riocypris. It seems to have selvage inwardly displaced on the right valve, but many other details of its morphology are obscure owing to the brief description. This new arrangement leaves the genus Eucypris with only one representative in Australia, Eucypris virens (Jurine, 1820). This is a cosmopolitan species, recorded from Australian inland waters by De Deckker (1982c). For the future investigation, it must be pointed out that many species described from South Africa, and assigned to the genus Eucypris by Sars (1924) obviously cannot belong there. This genus is in urgent need of revision and this may lead to the conclusion that at least Riocypris and Koencypris are its junior synonyms, because the morphology of the maxillular palp and length ratio between basal setae on the walking leg are the same in these genera. Also, the morphology of the male reproductive organs and prehensile palps are identical in Eucypris and Riocypris. Another genus, which has the same appearance of the maxillular palps and male sexual features, is the Australian genus Alboa described by De Deckker (1981a) from South Australia. This genus was erroneously placed in the subfamily Cyprinotinae by De Deckker (1981a), and should instead be in the subfamily Eucypridinae. In contrast to both Eucypris and Riocypris, the left valve in the genus Alboa has inwardly displaced selvage, while it is peripheral on the right valve. Therefore, the subfamily Eucypridinae has the following genera: Alboa, Eucypris, Prionocypris, Riocypris, Tonacypris, and Ttrajancypris. In my opinion the tribe Mytilocypridini, formed and placed in the Eucypridinae by De Deckker (1974) should be removed from the subfamily because the species of the tribe have a very different morphology of the male reproductive organs, including Zenker's organs with more than 60 rosettes and symmetrical prehensile palps. The position of Mytilocypridini is uncertain, but it is more closely related to the gigantic ostracod genera of the subfamily Megalocypridinae Rome, 1965, than to the subfamily Eucypridinae.

\section{Riocypris hinzeae sp. nov.}

Figures 1-5

\section{Material examined}

\section{Holotype}

Australia: Western Australia: $\delta$, Friday Well, Depot Springs, Murchison region, 2804'S, $12004 \mathrm{H}$, 28 June 2000 , W.F. Humphreys, S. Hinze (BES: 8410 ) (WAM C 35693, slide).

\section{Allotype}

Australia: Western Australia: $q$, collected with holotype (WAM C36694, slide). 

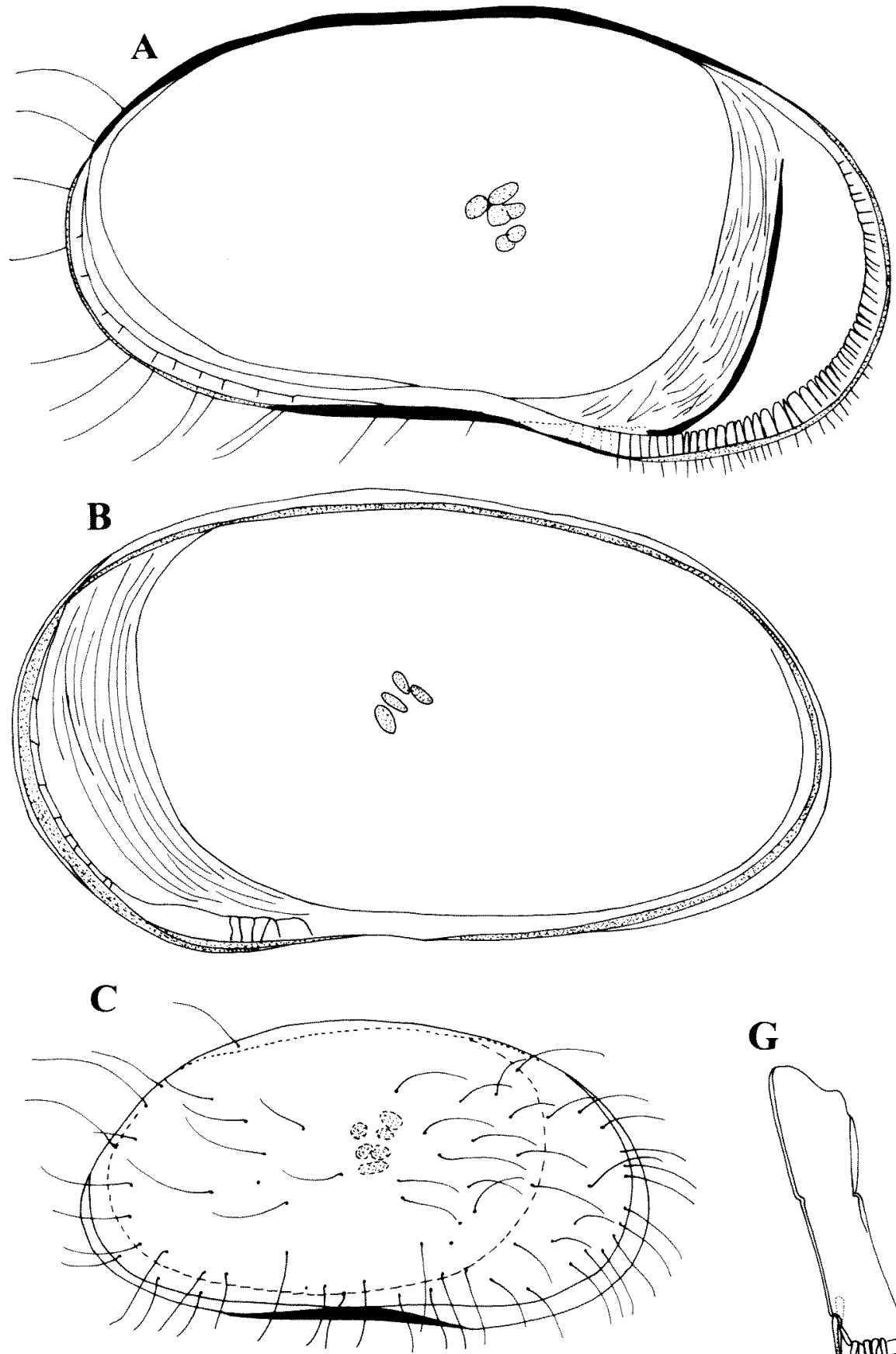

G

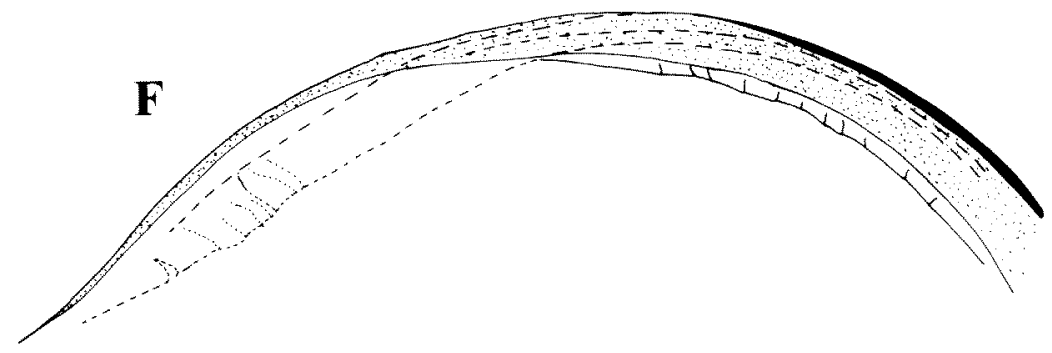
A, B
C, D : E
$\mathbf{F}$

$\mathbf{G}_{2} \mathbf{H}$

Figure 1 Riocypris hinzei sp. nov., holotype male: A, left valve, internal view; B, right valve, internal view; C, carapace, lateral view from left side; $D$, carapace, dorsal view; $E$, carapace, ventral view; $F$, right valve, anterior margin; $\mathrm{G}$, maxillular palp; $\mathrm{H}$, tooth on the third endite of maxillula. Scales $=0.1 \mathrm{~mm}$. 


\section{Paratypes}

Australia: Western Australia: 5 \&, 18 q, 10 juveniles, collected with holotype (WAM C35695, in alcohol)

\section{Other material}

Australia: Western Australia: 2 , Puncture Well, Depot Springs, Murchison region, $28^{\circ} 07^{\prime} \mathrm{S}, 120^{\circ} 05^{\prime} \mathrm{E}$, 28 June 2000 , W.F. Humphreys, S. Hinze (BES: 8417) (WAM C35696, in alcohol); 1 \&. New Well, Murchison region, 28 54'S, $119^{\circ} 10^{\prime} \mathrm{E} 15$ May 2001, W.F. Humphreys, C.H.S. Watts, S. Cooper (BES: 7280) (WAM C35697, in alcohol); 14 \&, 11 ?, 2 juveniles, Friday Well, Depot Spring Station, Murchison region, 28 $03^{\prime} \mathrm{S}, 120^{\circ} 04^{\prime} \mathrm{E}, 14 \mathrm{May} 2001$, W.F. Humphreys, C.H.S. Watts and S. Cooper (BES: 6649) (WAM C35698, in alcohol).

\section{Diagnosis}

The new species differs from all its congeners by the following combination of characters: dorsal margin of the carapace evenly rounded, almost flat; carapace surface smooth; anterior seta on the caudal ramus very short, not reaching $1 / 3$ of length of anterior claw.

\section{Description}

\section{Male (holotype)}

Length $1.04 \mathrm{~mm}$. Greatest height in front of middle, equalling $51 \%$ of length (Figure $1 \mathrm{~A}-\mathrm{C}$ ). Greatest width around middle, equalling $44 \%$ of length (Figure 1D). Carapace elliptical in lateral view. Anterior margin wider than posterior one; dorsal margin slightly rounded; ventral margin straight. Left valve (Figure 1A), with small dorsal flange; selvage peripheral all around margins, inner list well developed anteriorly, much lesser posteriorly. Inner calcified lamella equalling $22 \%$ of length anteriorly, and only 5\% posteriorly. Marginal pore canals straight and longer around mouth region. Right valve (Figure $1 \mathrm{~B}$ ) without well developed inner list. Salvage displaced internally all around free margins (Figure 1F). Right valve smaller than left one (Figure 1C). Left valve overlaps right one on all free margins (Figure $1 \mathrm{C}$ E). Carapace surface covered with hairs and surface not ornamented.

Antennula (Figure 3B, C) 7-segmented. Protopod with both exopodal setae developed. Proximal coxobasal seta missing, while distal one well developed. First endopodal segment with one anterior seta, not reaching middle of following segment. Second segment with one posterior and one anterior seta, both very short. Third endopodal segment with two short posterior and two long anterior setae. Fourth and fifth segments with four long swimming setae. Terminal segment with one aesthetasc, two long swimming setae and one half as long as aesthetasc. Aesthetasc eight times longer than terminal segment. Length ratios between five terminal segments: $4.6: 2: 1.4: 1.7: 1$. Swimming setae extending far beyond terminal segment (Figure 3C).

Antenna (Figure $3 \mathrm{~A}$ ) with swimming setae reaching tip of terminal claws. Shortest seta among them not reaching middle of penultimate segment. Penultimate segment medially with two setae on exterior side and four setae on interior side. Setae $z 1$ and $z 2$ transformed into long claws, as long as first endopodal segment, $z 3$ seta like and reaching middle of terminal claws. Claw G2 as long as transformed $z$ setae, while claws G1 and G3 transformed into setae, former one reaching $2 / 3$ of terminal claws, later one two times longer than terminal segment. Terminal segment with claw Gm well developed and almost reaching tip of other claws, while Gm less than half as long as Gm. Aesthetasc $Y 0.5$ times as long as first endopodal segment, y2 reaching distal end of terminal segment, while y3 three times longer than same segment. Length ratios between endopodal segments equalling $7: 5: 1$.

Mandibula (Figure 4A, C, E) with strong coxa bearing eight strong teeth (Figure $4 \mathrm{~A}, \mathrm{E}$ ). Palp with both $S$ setae well developed. Alpha seta bare and short. Second segment with $3+2$ setae in bunch, and three setae on external side. Gamma seta on penultimate segment short, stout and covered with short settulae. Terminal segment with one strong claw.

Rake like organ (Figure 4B) with 11 and 12 teeth.

Maxillular palp (Figure 1G) with six long and one short seta (situated on opposite side from long ones) on penultimate segment. Terminal segment elongated 3 times longer than wide. Teeth on first endite slightly serrated (Figure $1 \mathrm{H}$ ).

First thoracopod (Figure 2B, C), with two "a" setae, and "b" and "d" seta on protopod. Endopod transformed into palps: right one (Figure $2 \mathrm{~B}$ ) with much stronger finger than left one (Figure 2C). Exopod with six rays.

Second thoracopod (Figure 2F) with two setae on basal segment: proximal one $(\mathrm{d} 1)$ more than three times longer than distal one (d2). Seta on first endopodal segment not reaching distal end of following segment, seta on following segment exceeding distal end of terminal segment. Both setae on penultimate segment short. Terminal claw 1.3 times longer than three endopodal segments combined.

Third thoracopod (Figure4D) with all three basal setae present. Generally, this appendage typical for entire family.

Caudal ramus (Figure 2D, H) with long and thin ramus, with raw of setae on posterior margin. Anterior seta very short, posterior one situated law on ramus and slightly exceeding its tip. Anterior 


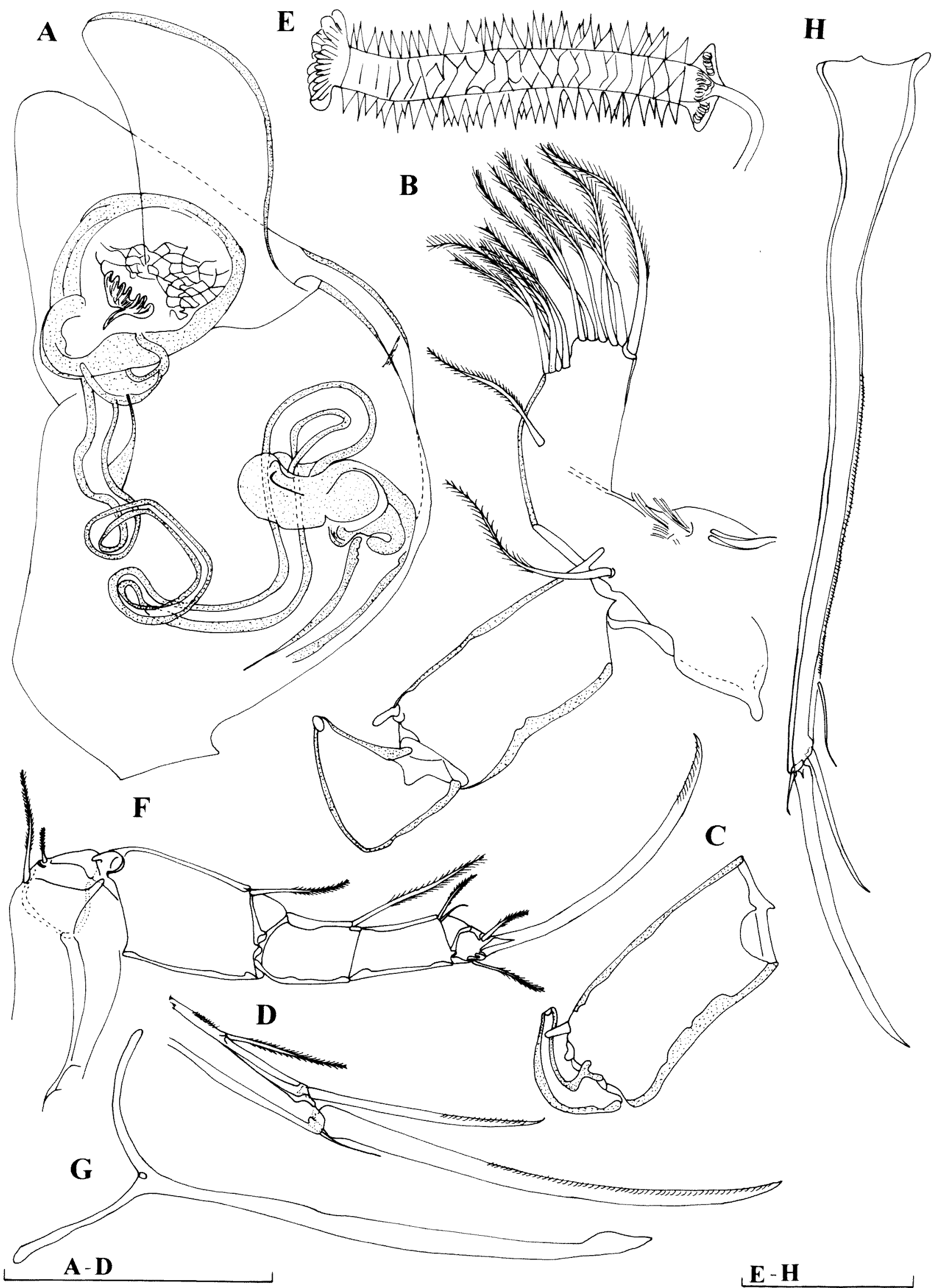

Figure 2 Riocypris hinzei sp. nov., holotype male: A, hemipenis; B, right prehensile palp; C, left prehensile palp; D, distal part of the caudal ramus; E, Zenker's organ; F, second thoracopod; G, attachment of the caudal ramus; $\mathrm{H}$, caudal ramus. Scales $=0.1 \mathrm{~mm}$. 


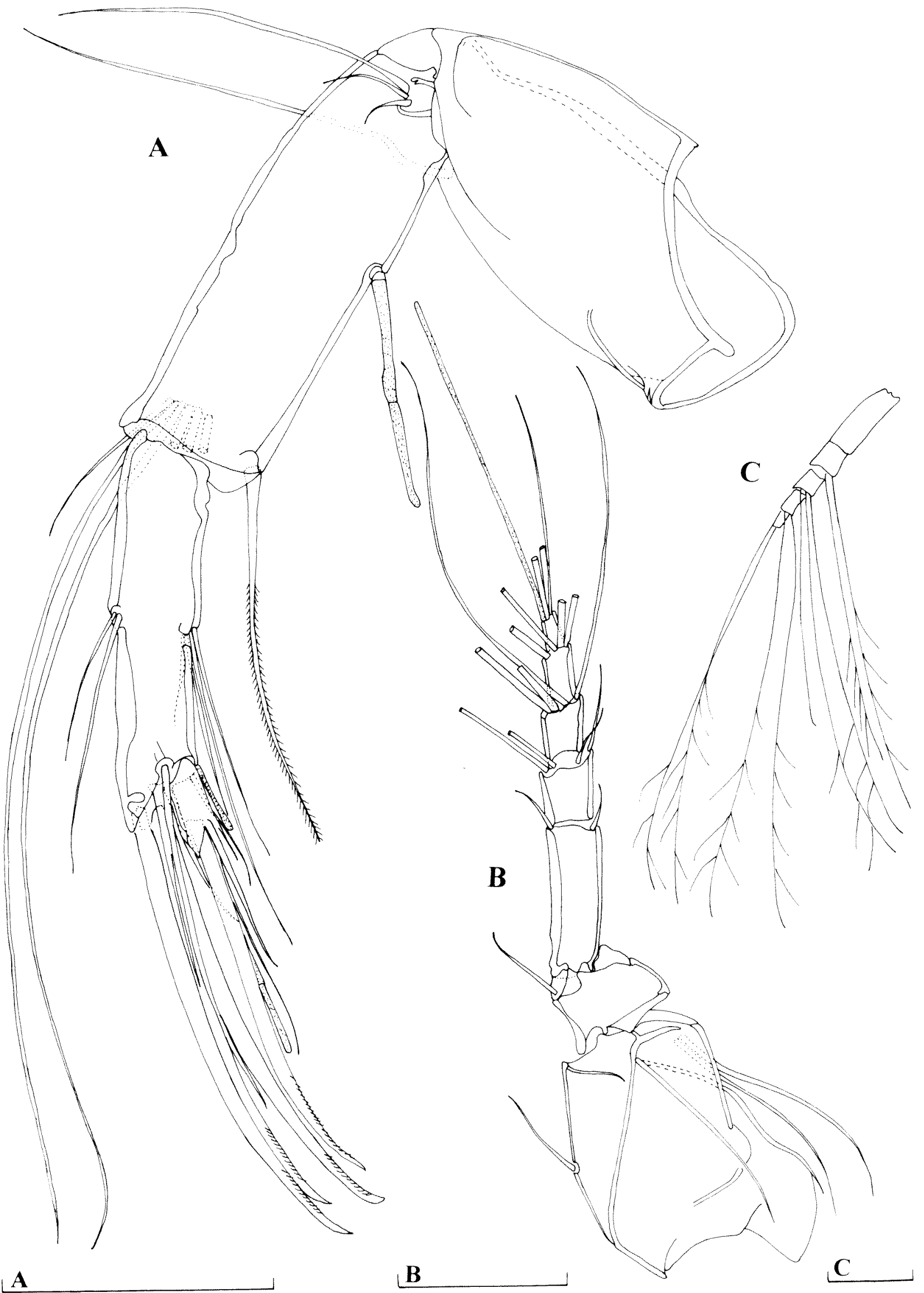

Figure 3 Riocypris hinzei sp. nov., holotype male: A, antenna; B, C, antennula. Scales $=0.1 \mathrm{~mm}$. 


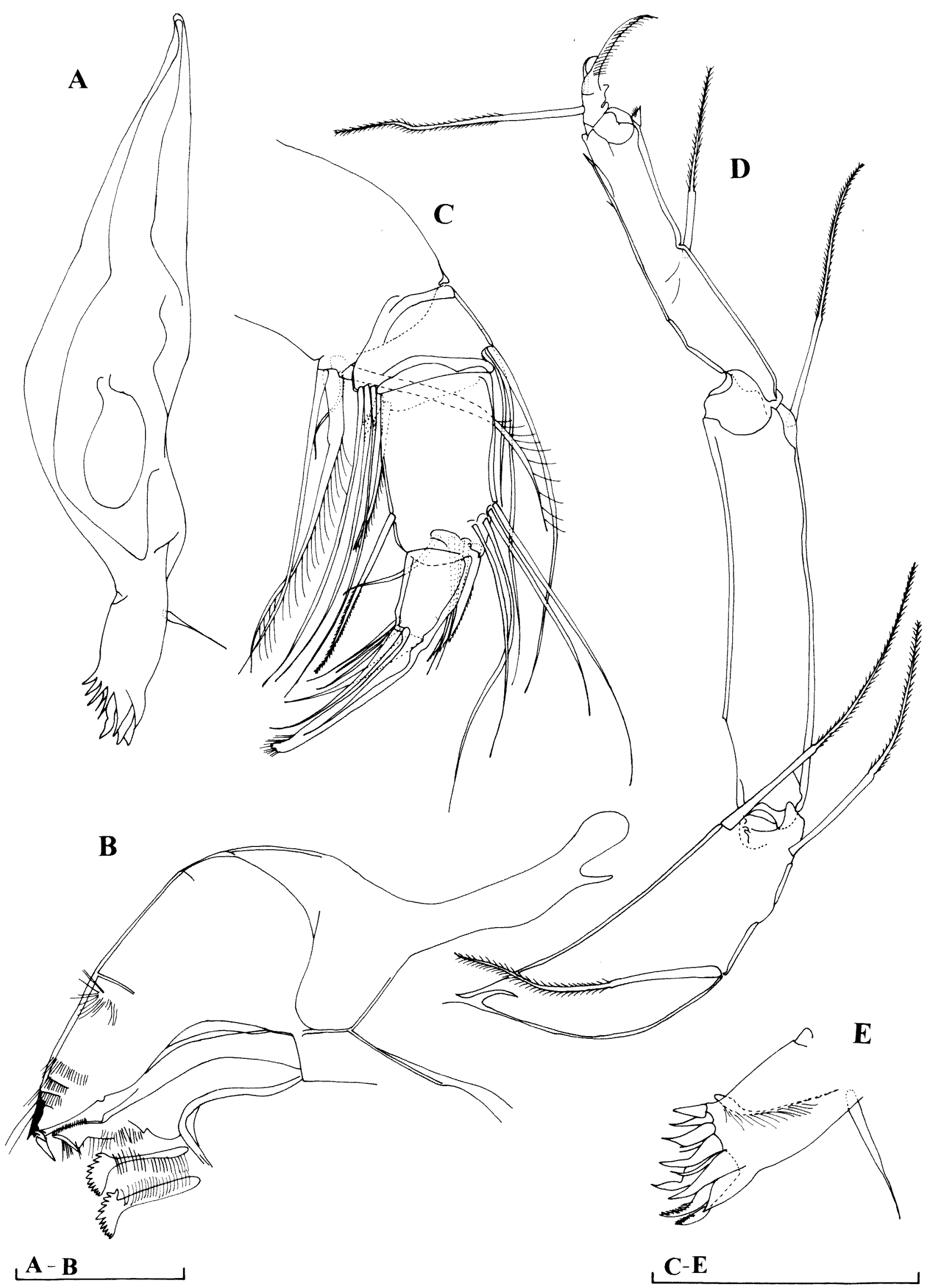

Figure 4 Riocypris hinzei sp. nov, holotype male: A, mandibular coxa, B, forehead and rake-like organ; C, mandibular palp; D, third thoracopod; $E$, distal part of the mandibular coxa. Scales $=0.1 \mathrm{~mm}$. 


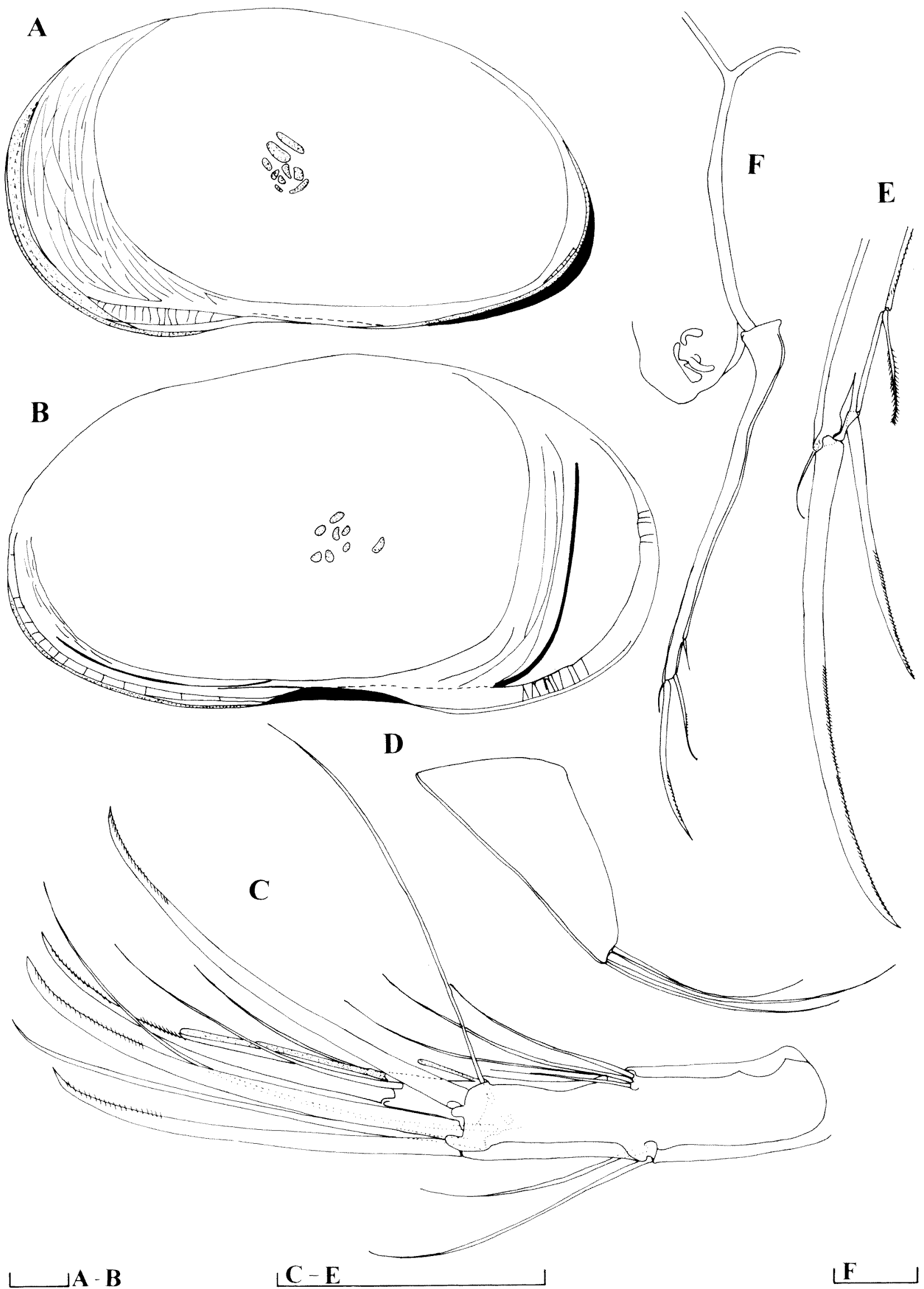

Figure 5 Riocypris hinzei sp. nov., allotype female: A, right valve, internal view; B, left valve, internal view; $C$, antenna, D, protopod of the first thoracopod; E, caudal ramus distal part; E, caudal ramus. Scales $=0.1 \mathrm{~mm}$. 
claw almost two times longer than posterior one. Length ratio of anterior margin and anterior claw equalling $2.3: 1$. Attachment of ramus (Figure $2 \mathrm{G}$ ) simple.

Hemipenis (Figure 2A) with coiled internal canals. Lobe " $a$ " higher than lobe " $b$ ", both lobes being bluntly pointed. Zenker's organ (Figure $2 \mathrm{E}$ ) with numerous rows of spines.

\section{Female (allotype)}

Length of carapace $1.09 \mathrm{~mm}$. Shape and other features same as in male.

Antenna (Figure 5C) with all three $z$ setae long and all claws well developed and subequally long.

First thoracopod (Figure 5D) with three setae on tip of endopod.

Caudal ramus and genital field (Figure 5E, F). Length ratio between anterior margin and anterior claw equalling $2.2: 1$. Genital field rounded.

All other appendages similar to one in male.

\section{Etymology}

The new species is named after Ms Susan Hinze, one of the collectors of the material. The name is to be treated as a noun in the genitive singular.

\section{Subfamily Cyprinotinae Bronstein, 1947}

\section{Genus Cyprinotus Brady, 1886}

Cyprinotus Brady, 1886a: 302.

\section{Type species}

Cyprinotus cingalensis Brady, 1886, by original designation.

\section{Remarks}

The genus Cyprinotus Brady, 1886 belongs to the subfamily Cyprinotinae, together with the genera Heterocypris Claus, 1892, Hemicypris Sars, 1903 and Homocypris Sars, 1924. The similarity between the genera Cyprinotus and Heterocypris has been discussed extensively in the literature (Meisch 2000). The only difference between the two genera is the presence of a hump-like dorsal extension on the right valve in the former genus, which can be traced through the geological record (Malz 1976). There are about 12 Recent species that can be assigned to Cyprinotus with certainty and many more Fossil ones. The genus is presently distributed in Africa, Southeast Asia and Australia. Pinto and Purper (1965) described Cyprinotus trispinosus Pinto and Purper, 1965 from Brazil, but this species can hardly belong to the genus Cyprinotus, because of the appearance of the caudal ramus and the terminal segment of the maxillula. Its long caudal ramus with very short setae suggests the species is more closely related to the genus Strandesia Stuhlmann, 1888 than to the genus Cyprinotus. In fact, the Triebel loop on the attachment of the caudal ramus, characteristic of the genus Strandesia, seems to be present in the species C. trispinosus (see plate 6, figure 5 in Pinto and Purper 1965). Where Australia is concerned, the following six species of the genus Cyprinotus have been recorded so far: C. carinatus (King, 1855), $C$. cingalensis Brady, 1889; C. dahli Sars, 1897; C. fuscus Henry, 1919; C. kimberleyensis McKenzie, 1966 and C. edwardi McKenzie, 1978). Cyprinotus carinatus and $C$. fuscus were described from south-eastern Australia (King 1855; Henry, 1919); C. cingalensis was originally described from Sri Lanka by Brady (1886a) but later recorded throughout Southeast Asia and found by Sars (1889) in Queensland. Cyprinotus kimberleyensis and $C$. dahli were both described from north-western Australia (Sars 1896; McKenzie 1966b). Cyprinotus kimberleyensis was also recorded from Japan (Okubo 1974). The species $C$. edwardi was described from Lake Wagin in Western Australia, but it is widely distributed in southern Australian lakes (McKenzie 1978). When McKenzie (1966b) described the species, he pointed out that it is closely related to $C$. cingalensis and $C$. dahli from which it differs by the smaller size and the shape of the hump. However, I have examined populations from the Pilbara in which both size (lengths from $1.05 \mathrm{~mm}$ to $1.4 \mathrm{~mm}$ ) and the appearance of the dorsal hump are very variable. Similar variation was observed in the northern Kimberley (Halse et al. 1996; S. Halse, pers. comm.). Therefore, I consider $C$. dahli and $C$. kimberleyensis to be junior synonyms of $C$. cingalensis. Their soft parts are almost identical, as are those of $C$. uenoi which was described from China (Brehm 1936) but was subsequently found both in Southeast Asia (Victor and Fernando 1981) and Japan (Okubo 1974). Thus C. uenoi is here also synonymized with $C$. cingalensis; this species is now seen to be widely distributed throughout Southeast Asia and north-western Australia. The same case is also with C. edwardi. McKenzie (1978) mentioned only a slightly more flexuous appearance of the carapace in dorsal view, as the only difference between his newly described species and both $C$. dahli and $C$. kimberleyensis. So, I consider $C$. edwardi a junior synonym of $C$. cingalensis. The two species recorded from the southeastern Australia differ from $C$. cingalensis by the pronounced ventral extension of the right valve.

\section{Cyprinotus cingalensis Brady, 1886 Figures 6-9}

Cyprinotus cingalensis Brady 1886a: 302, plate 38, figures 28-30; Sars 1889: 25, plate 1, figures 5-6, plate 3, figure 12; Victor and Fernando, 1979: 180 , figures $125-126$.

Cyprinotus dahli Sars 1896: 24, plate 4, figures 1-5. New synonymy. 


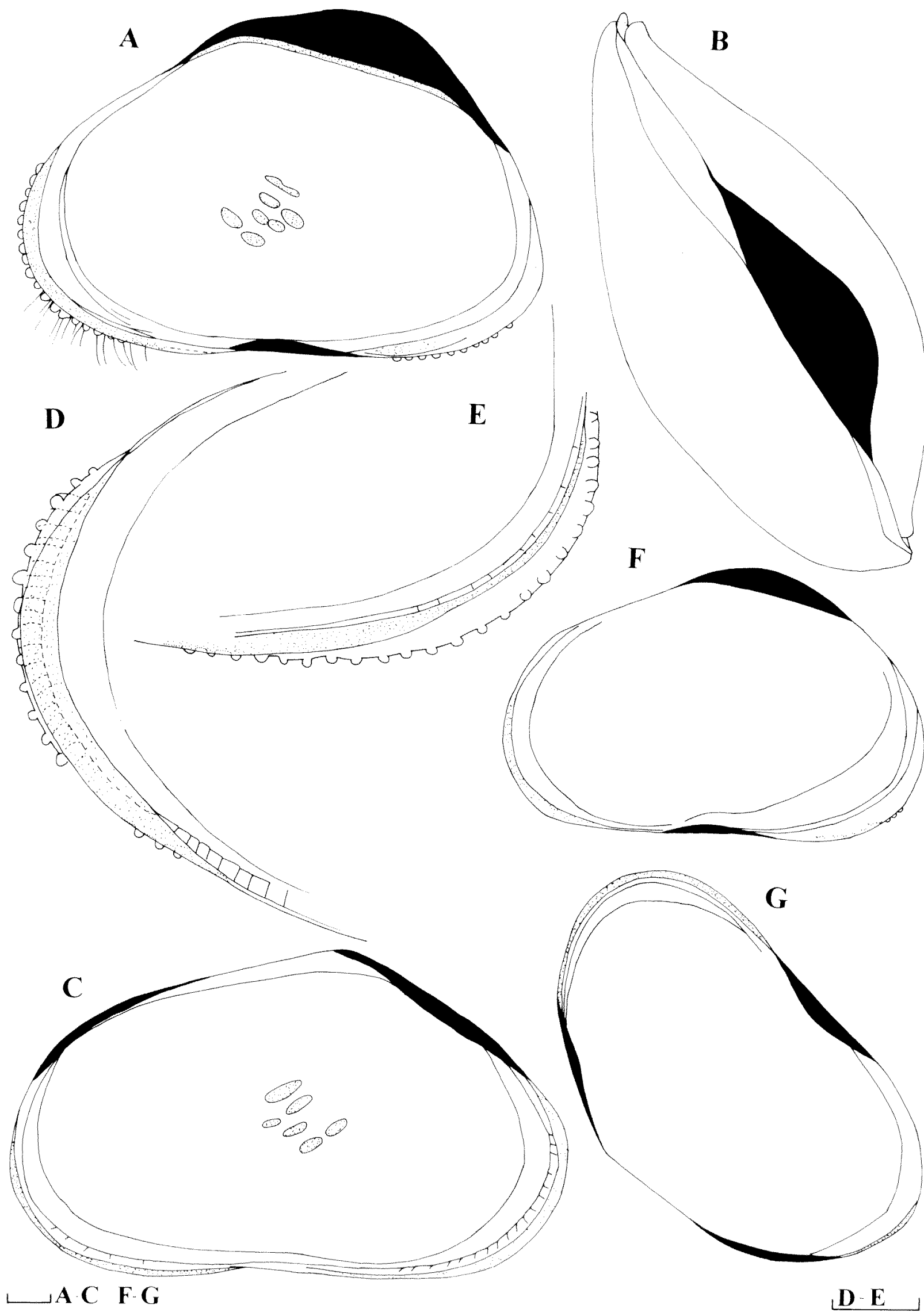

Figure 6 Cyprinotus cingalensis Brady, 1889, A-E, male (length, $1.3 \mathrm{~mm}$ ) from Government Well $\# 40$; F-G, male (length, $1.05 \mathrm{~mm}$ ) from Ten Mile Well: $A$, right valve, internal view; $B$, carapace, dorsal view; $C$, left valve, internal view; D, right valve, anterior margin; E, right valve, posterior margin; F, right valve, internal view; $G$, left valve, internal view. Scales $=0.1 \mathrm{~mm}$. 


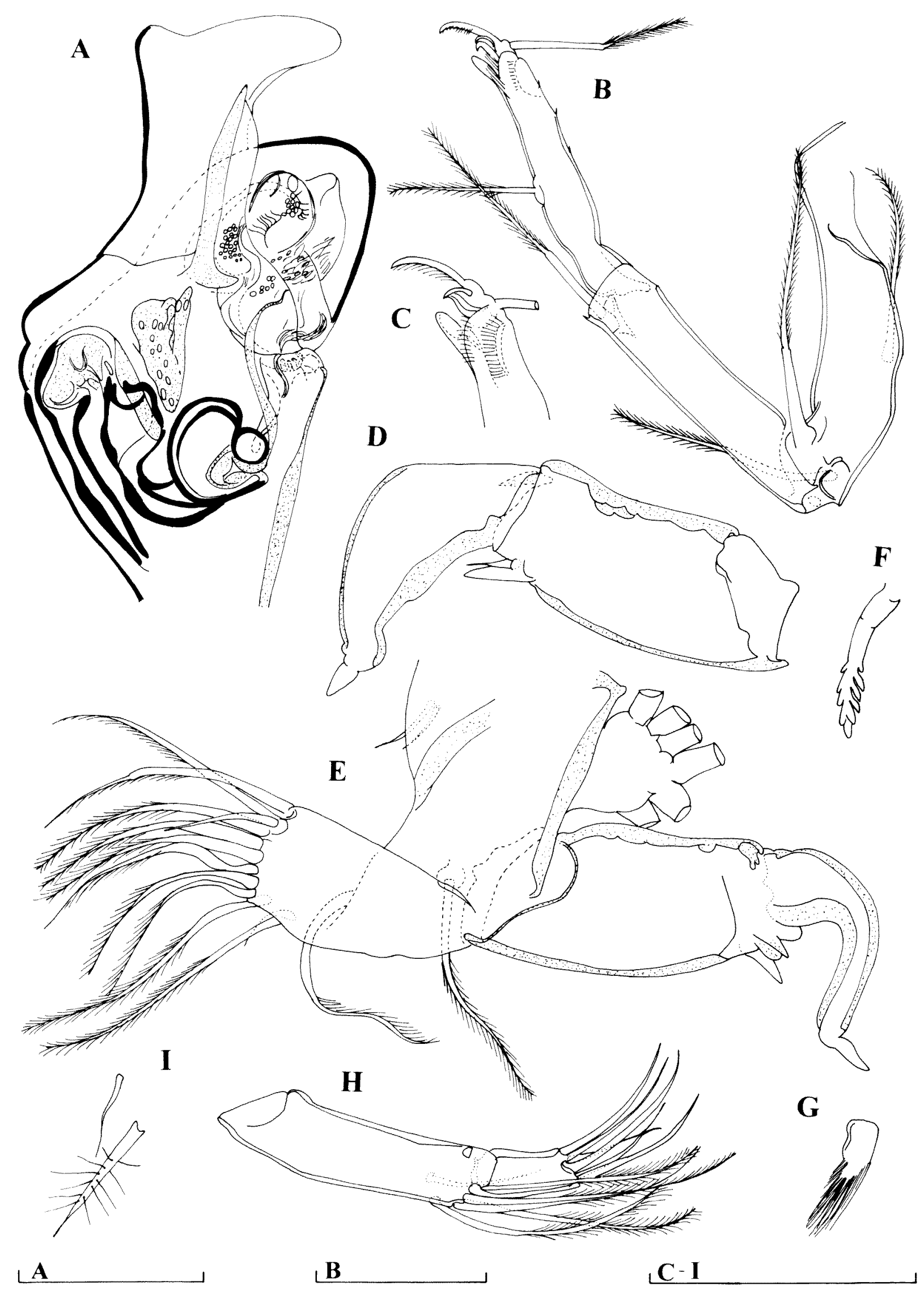

Figure 7 Cyprinotus cingalensis Brady, 1889, male (length, $1.3 \mathrm{~mm}$ ) from Government Well \#40: A, hemipenis; B, third thoracopod; $C$, third thoracopod, distal part; $D$, right prehensile palp; E, left prehensile palp; $F$, tooth on the third thoracopod endite of the maxillular palp; $G$, gamma seta on the mandibular palp; $H$, maxillular palp; I, alpha and beta setae on the mandibular palp. Scales $=0.1 \mathrm{~mm}$. 
Cyprinotus uenoi Brehm 1936: 374, figures 1-4; Okubo, 1974: 63, figure 3; Victor and Fernando, 1981: 13, figures 1-17. New synonymy.

Cyprinotus kimberleyensis McKenzie 1966b: 262, figures 2A-F; Okubo, 1974: 66, figures 2, 4. New synonymy.

Cyprinotus edwardi McKenzie 1978: 182, figures 8 $10,29,52-57$. New synonymy.

\section{Material examined}

Australia: Western Australia: 1 o, 2 , Government Well \#40, Savory 2, Pilbara Region, 23०51'49"S, $120^{\circ} 09^{\prime} 02.4^{\prime \prime E}, 21$ June 2004, M. Scanlon, J. Cocking (PSS 280) (WAM C35699-35701, on slides); 1 \&, 1 empty shell, 6 half shells, Helen's Well, Pilbara Region, 20 52'13.1'S, $120^{\circ} 20^{\prime} 44.2^{\prime \prime} \mathrm{E}, 12$ September 2004, M. Scanlon, J. Cocking (PSS 404) (WAM C35702, in alcohol); 46 \&, 22 juveniles and 100 half and empty shells, Ten Mile Well, WAR 11, Pilbara Region, 20 51'34.2"S, 120 32'45"E, 11 September 2004, M. Scanlon, J. Cocking (PSS 401) (WAM C35703, in alcohol); numerous whole animals, half and empty shells, Ten Mile Well, WAR 11, Pilbara Region, 20 51'34.2"S, 120 32'45"E, 7 May 2005, M. Scanlon, J. Cocking (PSS 401) (WAM C35704, in alcohol).

\section{Redescription}

Male

Length of left valve around $1.3 \mathrm{~mm}$. Greatest height in front of middle, equalling $62 \%$ of length (Figure 6C). Right valve smaller than left one and $1.2 \mathrm{~mm}$ long; greatest height situated behind middle and equalling $68 \%$ of length (Figure $6 \mathrm{~A}$ ). Greatest width behind middle, equalling $45 \%$ of length (Figure 6B). Carapace subtriangular in lateral view. Anterior and posterior margins equally wide; dorsal margin highly arched; ventral margin straight. Left valve (Figure 6C), with small dorsal flange; selvage peripheral all around margins. Inner calcified lamella equalling only $8 \%$ of length both anteriorly and posteriorly. Marginal pore canals straight and short. Right valve (Figure 6A) with well developed dorsal flange which overlaps left valve. Salvage displaced internally on both anterior and posterior margins (Figure 6D, E); both free margins carrying row of blunt teeth. Left valve overlaps right one on all free margins, except dorsally. Carapace surface covered with hairs and surface ornamented with small pits (Figure 9A).

Antennula (Figure 9E) 7-segmented. Protopod with both exopodal setae developed. Proximal coxobasal seta transformed into sensory organ, while distal one well developed. First endopodal segment with one anterior seta, not reaching middle of following segment. Second segment with one posterior and one anterior seta, both very short. Third endopodal segment with two short posterior and two long anterior setae. Fourth and fifth segments with four long swimming setae each. Terminal segment with one aesthetasc, two long swimming setae and one half as long as aesthetasc. Length ratios between five terminal segments: 2.9 : $1.9: 1: 1: 1$. Swimming setae extending far beyond terminal segment.

Antenna (Figure 8A, E) with swimming setae exceeding tip of terminal claws. Shortest seta among them reaching middle of penultimate segment. Penultimate segment medially with two setae on exterior side and four setae on interior side. Setae $z 1$ and $z 2$ transformed into long claws, $z 3$ seta like. Claw G2 long, G1 short but seta like, G3 transformed into seta. Terminal segment with claw $\mathrm{Gm}$ well developed and almost reaching tip of other claws, while Gm less than half as long as Gm. Aesthetasc $Y 0.3$ times as long as first endopodal segment, y3 as long as terminal segment. Length ratios between endopodal segments equalling 4 : $3.5: 1$.

Mandibular seta alpha tiny, beta seta better developed (Figure 7I), while gamma seta conical, short and strong (Figure $7 \mathrm{G}$ ).

Maxillular palp (Figure $7 \mathrm{H}$ ) with six long and one short seta (situated on opposite side from long ones) on penultimate segment. Terminal segment elongated two times longer than wide. Teeth on first endite strongly serrated (Figure $7 \mathrm{~F}$ ).

First thoracopod (Figure 7D, E), with two "a" setae, and " $b$ " and " $d$ " seta on protopod. Endopod transformed into palps: right one (Figure 7D) with much stronger finger than left one (Figure $7 \mathrm{E}$ ). Exopod with six rays.

Second thoracopod (Figure 9D) with one seta on basal segment. Seta on first endopodal segment not reaching distal end of following segment, seta on following segment exceeding distal end of terminal segment. Terminal claw 1.3 times longer than three endopodal segments combined.

Third thoracopod (Figure 7B, C) with all three basal setae present. Generally, this appendage typical for entire family.

Caudal ramus (Figure 8C) with long and thin ramus, with row of setae on posterior margin. Anterior seta reaching $1 / 3$ of anterior claw, posterior one situated law on ramus and almost reaching tip of posterior claw. Anterior claw more than two times longer than posterior one. Length ratio of anterior margin and anterior claw equalling 1.4: 1. Attachment of ramus (Figure 8B) simple.

Hemipenis (Figure 7A) with coiled internal canals. Lobe "a" higher than lobe "b" and foot-like; lobe "b" rounded. One well-chitinised lobe present between lobes " $a$ " and " $b$ ".

\section{Fonale}

Length of carapace $1.3 \mathrm{~mm}$. Shape and other features same as in male (Figure 9A, B). 


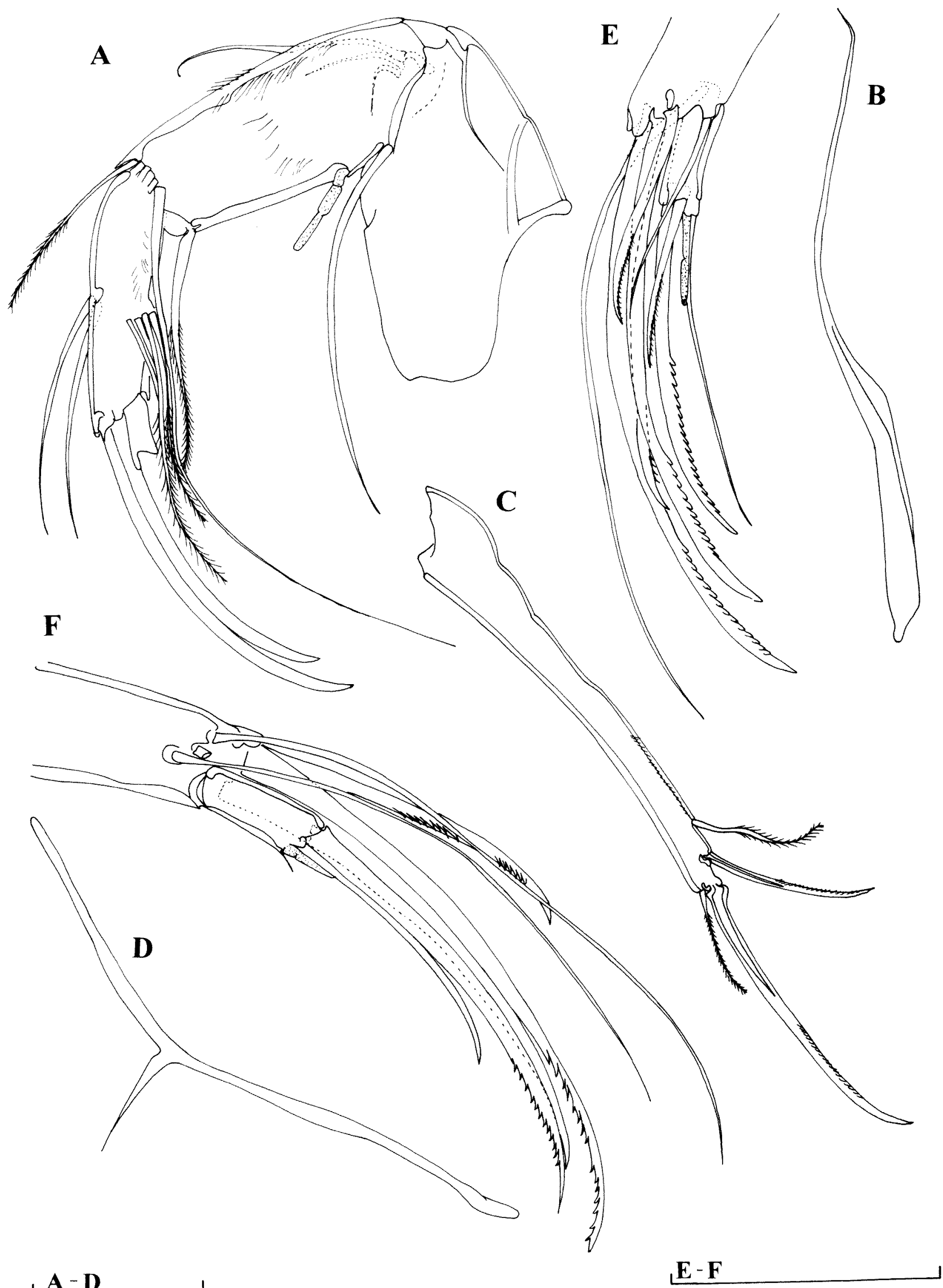

Figure 8 Cyprinotus cingalensis Brady, 1889, A-C, E male (length, $1.3 \mathrm{~mm}$ ) from Government Well \#40; D, F female (length, $1.3 \mathrm{~mm}$ ) from Government Well $\$ 40$ : A, antenna; B, attachment of the caudal ramus; C, caudal ramus; $D$, attachment of the caudal ramus; $E, F$, antenna, detail. Scales $=0.1 \mathrm{~mm}$. 


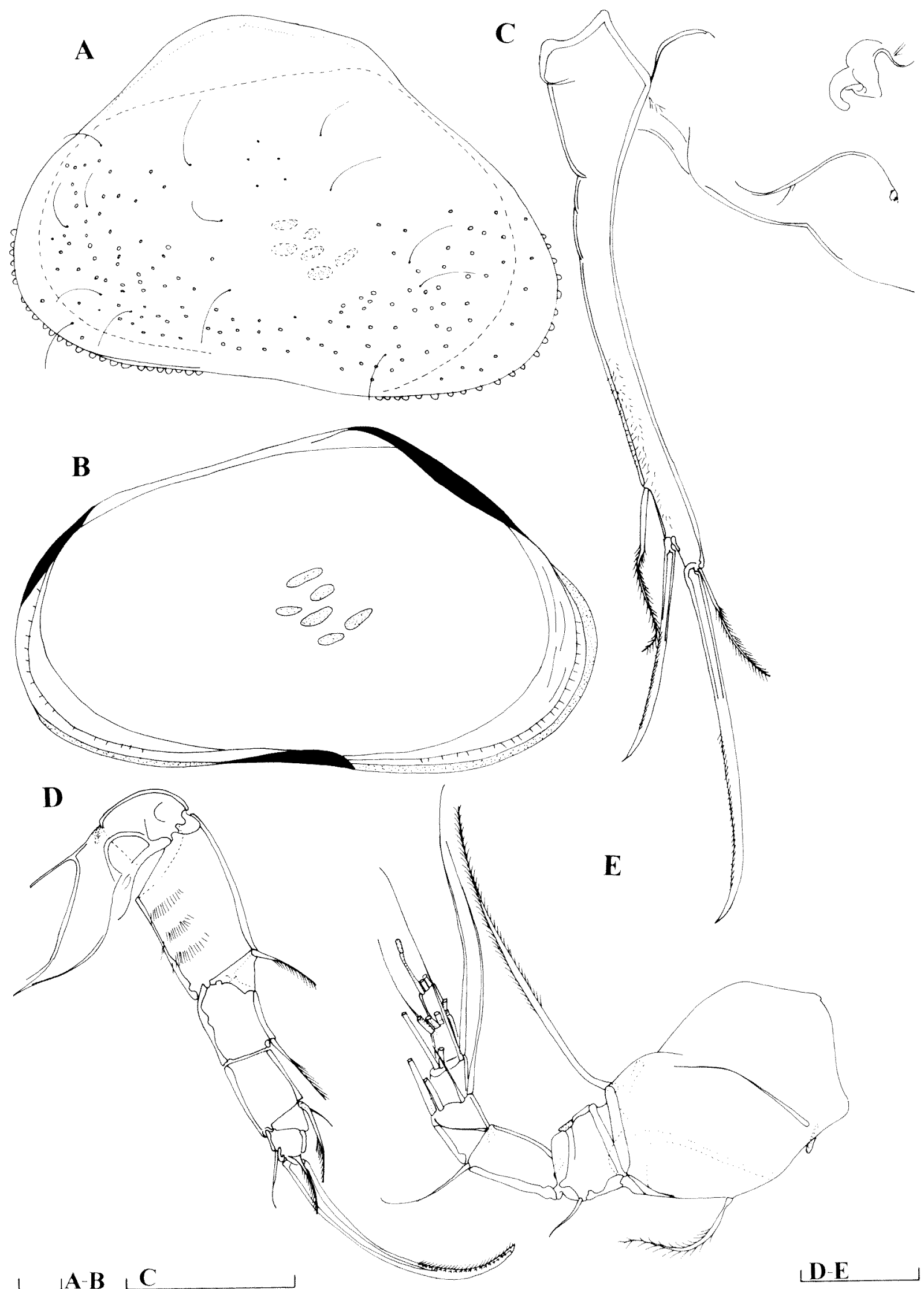

Figure 9 Cyprinotus cingalensis Brady, 1889, female (length, $1.3 \mathrm{~mm}$ ) from Government Well $\sharp 40$ : A, carapace, lateral view from right side; $B$, left valve, internal view; $C$, caudal ramus and the genital field; $D$, second thoracopod; $\mathrm{E}$, antennula. Scales $=0.1 \mathrm{~mm}$. 
Antenna (Figure $8 \mathrm{~F}$ ) with all three $\mathrm{z}$ setae long, claw G2 being much shorter than other long claws.

Caudal ramus and genital field (Figure 9C). Length ratio between anterior margin and anterior claw equalling $1.4: 1$. Genital field rounded.

All other appendages similar to those in male.

\section{Subfamily ?Cypridinae Baird, 1845}

\section{Genus Bennelongia De Deckker and McKenzie, 1981}

Bennelongia De Deckker and McKenzie 1981: 53.

\section{Type species}

Bennelongia harpago DeDeckker \& McKenzie, 198 , by original designation.

\section{Remarks}

The genus Bennelongia DeDeckker and McKenzie, 1981, was described and is so far only known from Australia. Today, it contains six recent species (DeDeckker and McKenzie 1981; DeDeckker 1981a, 1982b): B. australis (Brady, 1886), B. barangaroo De Deckker, 1981, B. harpago De Deckker and McKenzie, 1981, B. nimala De Deckker, 1981, B. pinpi De Deckker, 1981, and B. tunta De Deckker, 1982. The genus was erected to distinguish the Australian group of species that are closely related to the genus Chlamydotheca Saussure, 1858, from those in South America, where most members occur. The Australian genus differs from Chlamydotheca mainly in having asymmetrical prehensile palps. Both genera were placed in the subfamily Cypridinae, but cannot remain there following the new diagnosis consequent on the revision of this subfamily (Martens 1990, 1992). The subfamily Cypridinae is characterized by " 8 "-shaped loops in the inner spermiducts but this is not present in either Bennelongia or Chlamydotheca. A revision of the genus Bennelongia is in progress (K. Martens and S. Halse, in preparation). The species presented in this paper is identified as B. australis (Brady, $1886)$ originally described in the genus Chlamydotheca by Brady (1886b), and it has a wide distribution in Australia. Unfortunately, the identity of most Bennelongia species is difficult to establish due to the variability in the carapace shape within one species and uniformity of the internal morphology. Therefore, the present identification remains uncertain until further revision of the genus.

\section{Bennelongia australis s. 1. (Brady, 1886) Figures 10-12}

Chlayidotheca australis Brady 1886b: 91, plate 9, figures 408 .
Bennelongia australis (Brady, 1886): DeDeckker 1981a: 95, figures 3-6.

\section{Material examined}

Australia: Western Australia: 3 \%, 19 \%, Irwin Well, Millstream Aquifer, Pilbara Region, $21^{\circ} 40$ 'S, $117^{\circ} 09^{\prime} \mathrm{E}, 20$ October 1996, W.F. Humphreys (BES: 4564) (2 \&, 1 \&, WAM C35705-35707, on slides; the remainder, WAM C35708, in alcohol); 124 ㅇ 29 , Irwin Well (net over outlet for two days), Pilbara Region, $21^{\circ} 40^{\prime} \mathrm{S}, 117^{\circ} 09^{\prime} \mathrm{E}, 20$ October 1996 , W.F. Humphreys (BES: 4013) (WAM C35709, in alcohol); 2 \& CP 3 11/81, Chinderwariner (Crystal) pool, Millstream, Pilbara Region, $20^{\circ} 33^{\prime} \mathrm{S}, 118^{\circ} 14^{\prime} \mathrm{E}, 20$ October 1996, W.F. Humphreys (BES: 4468) (WAM C35710, in alcohol).

\section{Additional description}

Male

Length around $1.7 \mathrm{~mm}$. Greatest height in midanterior, equal to $50 \%$ of length (Figure 10C, D). Greatest width around middle, equalling $62 \%$ of length (Figure 10A, B). Carapace elliptical in lateral view. Anterior and posterior margins equally wide; dorsal margin slightly rounded; ventral margin straight or slightly concave. Left valve (Figure 10C), with small dorsal flange; selvage peripheral all around margins, inner list well developed anteriorly, much lesser posteriorly. Inner calcified lamella equalling $12 \%$ of length anteriorly, and only $6 \%$ posteriorly. Marginal pore canals straight. Right valve (Figure 10D) without well developed inner list. Selvage displaced internally on front margin. Anteroventral "beak" better developed on right valve than left valve. Left valve overlaps right one on all free margins (Figure 10A, B, E). Carapace surface covered with hairs and ornamented with shallow pits.

Antenna (Figure 11C) with swimming setae exceeding tip of terminal claws. Penultimate segment medially with two setae on exterior side and four setae on interior side. Setae $z 1$ and $z 2$ transformed into long claws, $\mathrm{z} 3$ seta like and reaching tip of terminal claws. Claw G2 as long as transformed $z$ setae, while claws G1 and G3 transformed. Terminal segment with claw $\mathrm{Gm}$ well developed and almost reaching tip of other claws, while Gm less than half as long as Gm.

Rake like organ (Figure 11I) with 7 teeth.

Maxillular palp (Figure 11EG) with six long and one short seta (situated on opposite side from long ones) on penultimate segment. Terminal segment elongated 3 times longer than wide. Teeth on first endite smooth (Figure 11F).

First thoracopod with two "a" setae, and " $b$ " and "d" seta on protopod. Endopod transformed into palps: right one (Figure 10G) with much stronger finger than left one (Figure 10F). Exopod with six rays. 

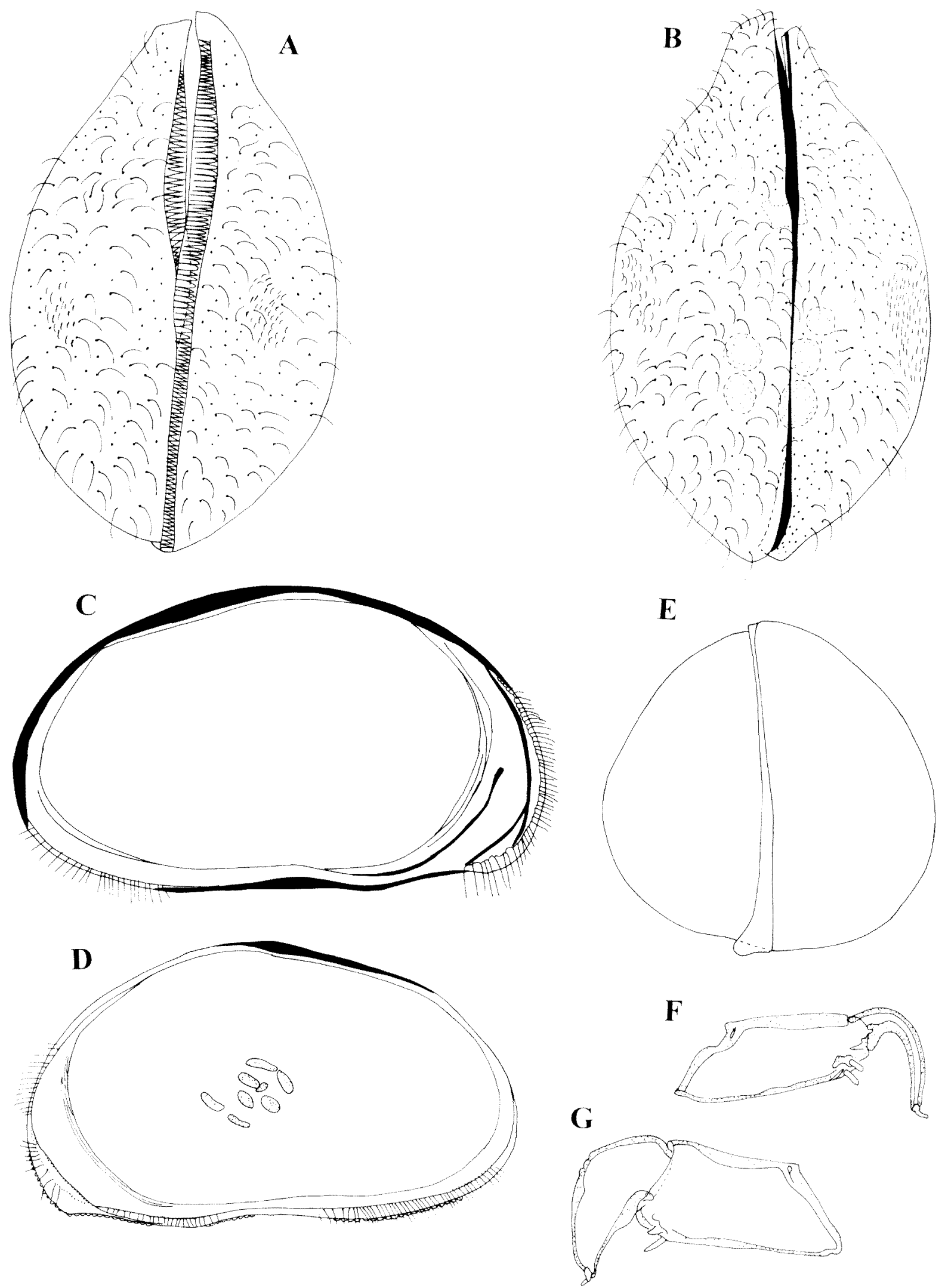

$\mathbf{A}-\mathbf{E}$

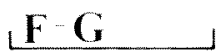

Figure 10 Bennelongia australis s. 1. (Brady, 1886), male (length, $1.7 \mathrm{~mm}$ ) from Irwin Well: A, carapace, ventral view: $B$, carapace, dorsal view; $C$, left valve, internal view; $D$, right valve, internal view; $E$, carapace, frontal view; $\mathrm{F}$, left prehensile palp; $\mathrm{G}$, right prehensile palp. Scales $=0.1 \mathrm{~mm}$. 


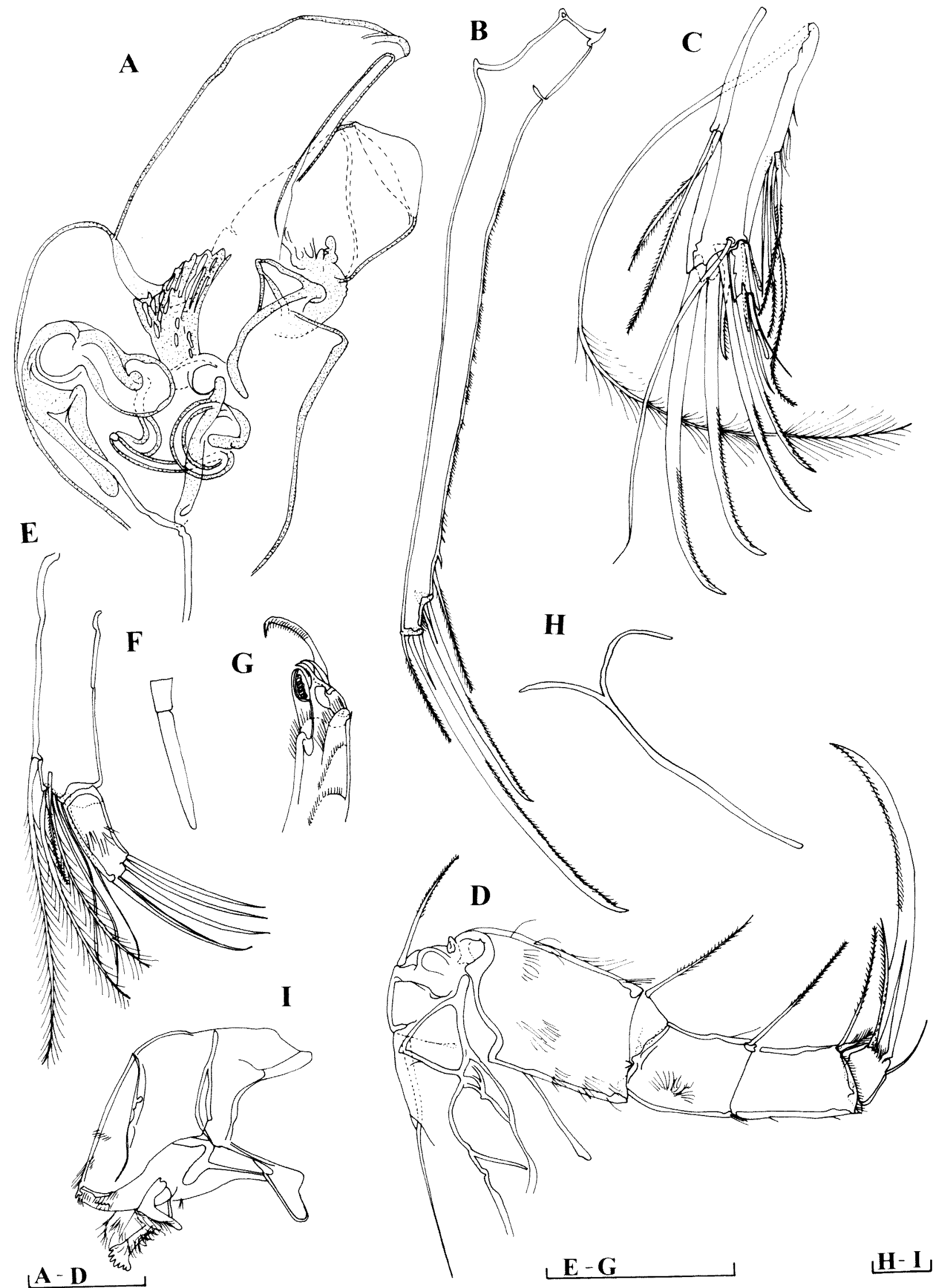

Figure 11 Bennelongia australis s. I. (Brady, 1886), male (length, $1.7 \mathrm{~mm}$ ) from Irwin Well: A, hemipenis; B, caudal ramus; $C$, antenna; $D$, second thoracopod; $E$, maxillular palp; $F$, tooth on the third endite of the maxillula; $G$, distal part of the third thoracopod; $\mathrm{H}$, attachment of the caudal ramus; I, forehead and rake-like organ. Scales $=0.1 \mathrm{~mm}$. 


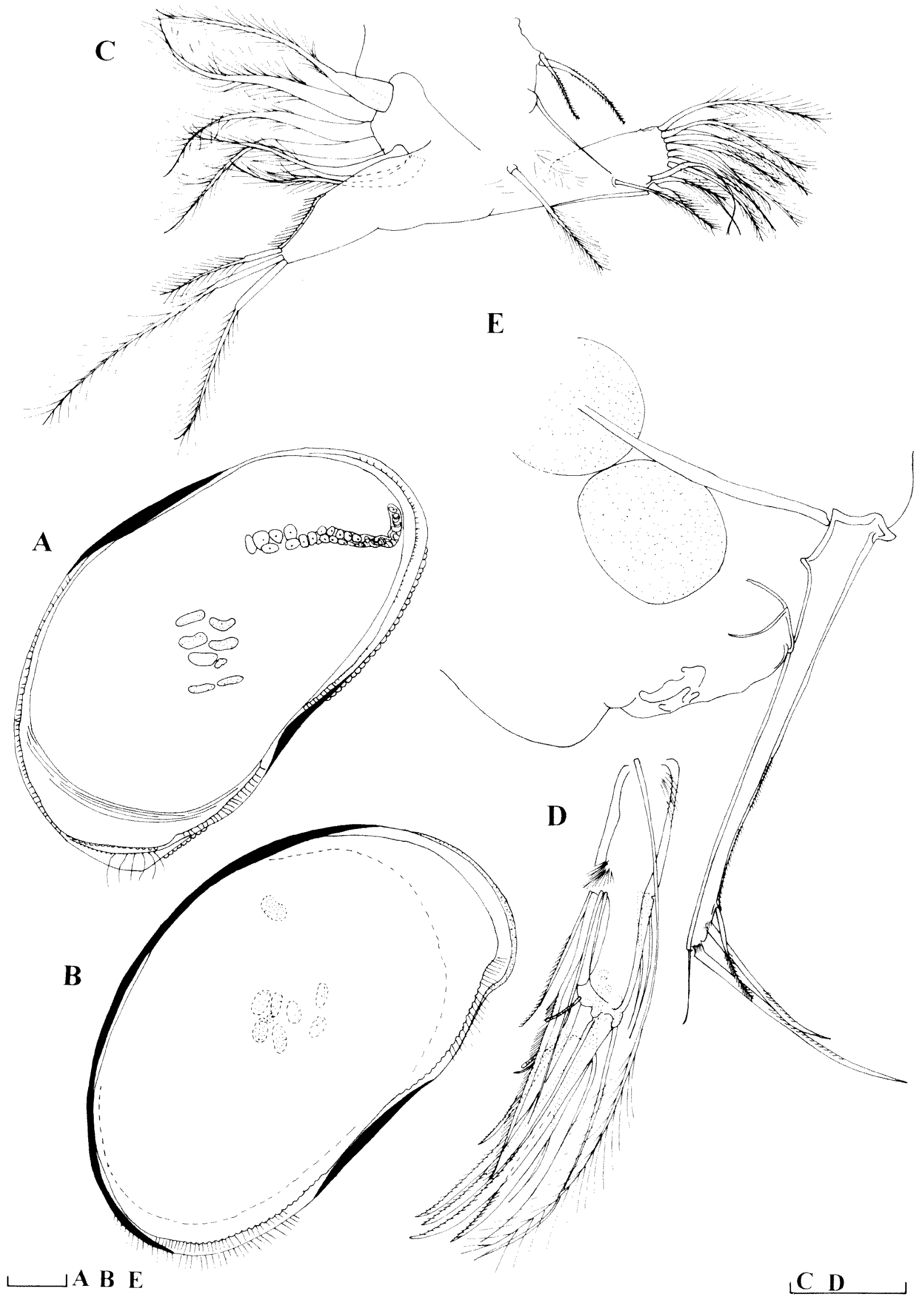

Figure 12 Bennelongia australis s. 1. (Brady, 1886), female (length, $1.7 \mathrm{~mm}$ ) from Irwin Well: A, right valve, internal view; $B$, left valve, internal view; $C$, first thoracopod; $D$, antenna; $E$, caudal ramus and the genital segment. Scale $=0.1 \mathrm{~mm}$. 
Second thoracopod (Figure 11D) with two setae on basal segment: proximal one (d1) more about two times longer than distal one $(\mathrm{d} 2)$.

Third thoracopod (Figure 11G) with all three basal setae present. Generally, this appendage typical for entire family.

Caudal ramus (Figure 11B) with long and thin ramus, with row of small spines on posterior margin. Anterior seta short and equally long as posterior one. Anterior claw almost two times longer than posterior one. Length ratio of anterior margin and anterior claw equalling 1.6: 1 . Attachment of ramus (Figure 11H) simple.

Hemipenis (Figure 2A) with coiled internal canals. Lobe "a" higher than lobe " $b$ ", both lobes being bluntly pointed.

\section{Female}

Length of carapace about $1.7 \mathrm{~mm}$. Shape and other features same as in male (Figure 12A-B).

Antenna (Figure 12D) with all three $z$ setae long and all claws well developed and subequally long.

First thoracopod (Figure 12D) with three setae on tip of endopod.

Caudal ramus and genital field (Figure 12E). Length ratio between anterior margin and anterior claw equalling $1.6: 1$. Genital field rounded.

All other appendages similar to one in male.

\section{ACKNOWLEDGEMENTS}

I would like to acknowledge the support of the Western Australian Museum Foundation Grant, which contributed to the finalisation of this paper. Many thanks to Dr Stuart Halse (Western Australian Department of Ecology and Conservation) and Dr William F. Humphreys (Western Australian Museum) for reading the manuscript and giving many useful suggestions. I also want to thank the Western Australian Museum for giving me the position of the Honorary Associate, enabling the use of the Museum's facilities.

\section{REFERENCES}

Brady, G.S. (1886a). Notes on Entomostraca collected by Mr. A. Haly in Ceylon. Journal of the Linnean Society 19: 293-317.

Brady, G.S. (1886b). Notes on freshwater Entomostraca from South Australia. Proceedings of the Scientific Meetings of the Zoological Society of London 1886: 82-93.

Brehm, V. (1936). Ostracoden aus Mandschuko. Annotationes Zoologicae Japonenses 15: 374-377.

Broodbakker, N.W. and Danielopol, D.L (1982). The chaetotaxy of Cypridacea (Crustacea, Ostracoda) limbs: proposal for a descriptive model. Bijdragen tot de Dierkunde 52: 103-120.

De Deckker, P. (1974). Australocypris, a new ostracod genus from Australia. Australian Journal of Zoology 22: 91-104.

De Deckker, P. (1976). Trigonocypris a new ostracod genus from Queensland. Australian Journal of Zoology 24: 145-157.

De Deckker, P. (1979a). Comparative morphology and review of Australia Notodromatinae Kaufmann, 1900. Senckenbergiana Biologica 59: 417-463.

De Deckker, P. (1979b). Ostracods from the mound springs area between Strangways and Curdimurka, South Australia. Transaction of the Royal Society of South Australia 103: 155-168.

De Deckker, P. (1981a). Taxonomy and ecology notes of some ostracods from Australian inland waters. Transaction of the Royal Society of South Australia 105: $91-138$.

De Deckker, P. (1981b). Taxonomic notes on some Australian Ostracods with description of new species. Zoologica Scripta 10: 37-55.

De Deckker, P. (1981c). On Eucypris fontana (Graf). Stereo Atlas of Ostracod Shells 8: 87-92.

De Deckker, P. (1982a). On Caboncypris nunkeri DeDeckker gen. et sp. nov. Stereo Atlas of Ostracod Shells 9: 125-132.

De Deckker, P. (1982b). On Bennelongia tunta De Deckker sp. nov. Stereo Atlas of Ostracod Shells 9: 117-124.

De Deckker, P. (1982c). Ostracods from Australian inland waters - notes on taxonomy and ecology. Proceedings of the Royal Society of Victoria 93: 43-85.

De Deckker, P. and McKenzie, K.G. (1981). Bennelongia, a new Cypridid ostracod genus from Australasia. Transaction of the Royal Society of South Australia 105: 53-58.

Halse, S.A. (2002). Diversity of Ostracoda (Crustacea) in inland waters of Western Australia. Verhandlungen der Internationalen Vereinigung für Limnologie 28: 914-918.

Halse, S.A. and McRae, J.M. (2004). New genera of "giant" ostracods (Crustacea, Cyprididae) from Australia. Hydrobiologia 524: 1-52.

Halse, S. A., Shiel, R. J. And Peterson, G. B. (1996). Waterbirds and aquatic invertebrates of swamps on the Victoria-Bonaparte mudflat, northern Western Australia. Journal of the Royal Society of Western Australia 79: 217-224.

Hartmann, G. and Puri, H.S. (1974). Summary of Neontolofical and Paleontological Classification of Ostracoda. Mitteilungen aus dem Hamburgischen Zoologischen Museum und Institut 70: 7-73.

Henry, M. (1919). On some Australian freshwater Copepoda and Ostracoda. Journal of the Royal Society of New South Wales 53: 29-48.

Karanovic, I. (2005a). On the genis Strandesia Stuhlmann, 1888 (Crustacea, Ostracoda, Cyprididae) with description of Strandesia kimberleyi n. sp. and a key to the extant species of the genus. Contribution to Zoology 74: 77-95.

Karanovic, I. (2005b). Comparative morphology of the Candoninae antennula, with remarks on the ancestral state in ostracods (Crustacea, Ostracoda) and proposed new terminology. Spixiana 28: 141-160. 
King, R.L. (1855). On Australian Entomostracans. Papers and Proceedings of the Royal Society of Tasmania 3 : $56-75$.

Klie, W. (1935). Süsswasser-Ostracoden aus Uruguay. Archiv für Hydrobiologie 29: 282-295.

Malz, H. (1976). Heterocypris vel Cyprinotus? Ist die Morphologie des Gehäuses entsceidend für die Bestimmung rezenter Ostracoden-Gattungen? Senckenbergiana Lethaea 57: 185-199.

Martens, K. (1986). Taxonomic revision of the Subfamily Megalocypridinae Rome, 1965 (Crustacea, Ostracoda). Koninklijke Academie voor Wetenschappen, Letteren en Schone Kunsten van Belgic, Klasse der Wetenschappen Jaargang 48 174: 1-79.

Martens, K. (1987). Homology and functional morphology of the sexual dimorphism in the antenna of Sclerocypris Sars, 1924 (Crustacea, Ostracoda, Megalocypridinae). Bijdragen tot de Dierkunde 57: $183-190$.

Martens, K. (1989). On the systematic position of the Eucypris clavata-group, with a description of Trajancypris gen. nov. (Crustacea, Ostracoda). Archir für Hydrobiologie, Supplement 83: 227-251.

Martens, K. (1990). Taxonomic revision of African Cypridini. Part I: the genera Cypris O. F. Müller, Pseudocypris Daday and Globocypris Klie (Crustacea, Ostracoda). Bulletin de l'Institut Roval des Sciences Naturelles de Belgique, Biologie 60: 127 172.

Martens, K. (1992). Taxonomic revision of African Cypridini. Part II. Description of Ramotha gen. nov. (Crustacea, Ostracoda). Annales of the South African Museum 102: 91-130.

Martens, K. (1998). General morphology of non-marine Ostracods. In: Martens, K. (ed.). Sex and Parthenogenesis: evolutionary ecology of reproductive modes in non-marine ostracods. Backhuys Publishers, Leiden, The Netherlands: $57-75$.

Martens, K., De Deckker, P. and Rossetti, G. (2004). On a new terrestrial genus and species of Scottinae (Crustacea, Ostracoda) from Australia, with a discussion on the phylogeny and the zoogeography of the subfamily. Zoologischer Anzeiger 243: 21-36.

McKenzie, K.G. (1966a). Mytilocypris, a new ostracode genus from Tasmania. Papers and Proceedings of the Royal Society of Tasmania 100: 27-30.

McKenzie, K.G. (1966b). Freshwater Ostracoda from North-Western Australia. Australian Journal of Marine and Freshwater Research 17: 259-279.
McKenzie, K.G. (1978). Ostracoda (Crustacea: Podocopida) from Southern Australian salt lakes, with the description of Retycypris new genus. Transaction of the Royal Society of South Australia 102: $175-190$.

Meisch, C. (1996). Contribution to the taxonomy of Pseudocandona and four related genera, with the description of Schellencandona nov. gen., a list of the Candoninae genera, and the key to the European genera of the subfamily (Crustacea, Ostracoda). Bulletin de la Sociéte des Naturalistes Luxembourgeois 97: 211-237.

Meisch, C. (2000). Freshwater Ostracoda of Western and Central Europe. In: Schwoerbel, J. and P. Zwick (eds). Süsswasserfauna von Mitteleuropa. Spektrum Akademischer Verlag, Gmbh. Heidelberg, Berlin 8/3: $1-522$.

Okubo, I. (1974). Two species of the genus Cvprinotus (Ostracoda, Cyprididae) from Japan. Researches on Crustacea 6: $58-70$

Pinto, I.D. and Purper, I. (1965). A new fresh-water ostracode Cyprinotus trispinosus Pinto et Purper, sp. nov., from southern Brazil, its ontogenis carapace variation and seasonal distribution. Escola de geologia de Porto Alegre: 1-53.

Sars, G.O. (1889). On some freshwater Ostracoda and Copepoda, raised from dried Australian mud. Christiania Videnskabs-Selskabs Forhandlinger 8: $1-73$.

Sars, G.O. (1896). On some West-Australian Entomostraca raised from dried sand. Archiv for Mathematik og Naturvidenskab 19: 1-35.

Sars, G.O. (1924). The fresh-water Entomostraca of the Cape Province (Union of South Africa). Part: Ostracoda. Annals of the South African Museum 22: 105-193.

Victor, R. and Fernando, C.H. (1979). The freshwater ostracods (Crustacea: Ostracoda) of India. Records of the Zoological Survey of India 74: 147-242.

Victor, R. and Fernando, C.H. (1981). Freshwater ostracods (Crustacea: Ostracoda) of the subfamily Cyprinotinae Bronstein, 1947 from Malaysia, Indonesia and the Philippines. Hydrobiologia 83: 1127.

Manuscript accepted 5 October 2007 